\title{
Some Considerations about Pain in the Child that was Born Premature
}

\author{
Maria Celeste Gomez* \\ Perinatal Psychologist, CIIPME-CONICET, Argentina
}

Submission: November 16, 2017; Published: November 28, 2017

*Corresponding author: Maria Celeste Gomez, Perinatal Psychologist, CIIPME-CONICET, Argentina; Email: gomezmariaceleste@gmail.com

\section{Short Communication}

Every single child born before completing the 37 weeks of gestational age (GA) is considered by major organizations such as UNICEF [1] and OMS [2] as premature. Because of their in maturity, these infants must face at the early beginnings of their lives hospitalization in a neonatal intensive care unit (NICU) which will take longer or lesser depending on their GA when born, their weight and their overall health condition. In that Unit they will undergo several interventions to make a diagnosis and treatments in pursuit of an adequate and soon recovery, and therefore get ready to be discharged and return home.

The Ibero-American Society of Neonatology [3] raise in their statistics that newborns with a GA of less than 32 weeks during hospitalization must undergo up to 14 possibly painful proceedings per day.

These kind of interventions, although made to improve the recovery of the child, are not harmless, and so investigators such as Moral Garcia and Fajardo [4] have reported painful sequelae in a short and long term amongst which we can evidence that the neurodevelopment and child behavior is affected; we can find pain sensitivity alterations, anatomical abnormalities, anxiety responses, defensive behavior, learning and memory deficit, decreased sensitivity to childhood habitual bumps and drops, and a major tendency to somatization once the early childhood has finished. Anand [5] in his trials had already postulated in relation to the sequelae produced by pain in the newborn, difficulties in the adaptation to the postnatal environment, generating problems in the relationship with parents and nourishment, both very important aspects when it's time to decide the discharge of the patient. We must take into consideration that the premature baby is not any individual but one that presents specific characteristics regarding maturity, an issue that will also affect his sensor perception of pain in an absolute opposite way to the one considered 30 years ago.

The immaturity of his system does not necessary mean the impossibility to sense pain, but the opposite. The required nervous structures are developed since very early gestational ages. Basso [6] states that nociceptor begin their maturity in an embryological level between the 6th and 8th gestational week. The bone marrow, the brain stem, the thalamus, and the somatosensory cortex (ascending parietal gyrus) and limbic system start developing in the $14^{\text {th }}$ week and around the 30th week it should be completed. But not only the ascendant mechanism is important when considering the pain, but also the descendant conduct, which enables the modulation of it, has a particular value in this cohort, as this conduct is the one that hasn't completely developed. So, we encounter individuals who are vulnerable to pain, which is found in a wider extent and with a longest lasting effect $[7,8]$. Cibeira [9] states that pain is an enigma and within it, important factors such as culture, the society and personal experience are combined, integrating within this last aspect the psychological dimension. According to Frankl V [10] pain is one of the three issues described in his tragic triad together with guilty and death. These items are part of our existence just like extreme situations that we can't help living, but indeed find the way to go through them.

In order to do this, regarding the premature newborn, thinking about the way we position ourselves as health professionals is of great importance, each of us in our role, but aiming at an inclusive and interdisciplinary labor. The premature child who is in a preverbal stage will not be able to express in words what he feels, but he will be able to do so, by means of his behavior and physiological values. Including parents in the neonatology service, taking into account the immaturity of these children and their unfavorable features against pain, will allow us to humanize this infant, considering him as a person with all his strata, collaborating this way in the sequelae reduction, providing him with a greater quality of life.

\section{References}

1. UNICEF (2010) Learning and schooling of the premature child.

2. World Health Organization (2015) 15 million babies are born too early 
3. Iberoamerican Society of Neonatology (2012) V SIBEN Consensus: Analgesia and neonatal sedation, Brazil.

4. Moral García T, Fajardo MF (2011) Management of stress and pain in the newborn. In Solá A. (Edn.), Neonatal care. Discovering the life of a sick newborn, Edimed, Argentina 2: 1381-1393.

5. Anand K, Hickey PR (1987) Pain and its effects in the human neonate and fetus. The new england journal of medicine 317(21): 1321-1329.

6. Basso G (2012) A premature birth: accompanying neurodevelopment (Edn.), Cesarini Hnos, Buenos Aires, Argentina.
7. Dinerstein A, Brundi M (1998) Pain in the premature newborn. Hospital Materno Infantil Ramón Sardá, 17: 97-192.

8. García M, Amaya E, Narváez Ramos R (2010) General considerations about pain. In Urbina-Medina $\mathrm{H}$ (Edn.), Pain in pediatrics, Panamericana, (2 ${ }^{\text {nd }}$ Edn.), Venezuela, South America, pp: 1-13.

9. Cibeira J (2006) Clinical treatment of pain, Corpus, Rosario, Santa Fé (Edn.), Argentina.

10. Frankl V (1991) The will to meaning, Herder, Barcelona (Edn.), Germany.

\begin{tabular}{l} 
Your next submission with Juniper Publishers \\
will reach you the below assets \\
- Quality Editorial service \\
- Swift Peer Review \\
- Reprints availability \\
- E-prints Service \\
- Manuscript Podcast for convenient understanding \\
- Global attainment for your research \\
- Manuscript accessibility in different formats \\
( Pdf, E-pub, Full Text, Audio) \\
- Unceasing customer service \\
Track the below URL for one-step submission \\
https://juniperpublishers.com/online-submission.php \\
\hline
\end{tabular}

